\title{
Morphological Changes of Skeletal Class III Malocclusion in Mixed Dentition with Protraction Combined Activities
}

\author{
Cambios Morfológicos en Maloclusión de la Clase Esquelética III \\ en Dentición Mixta con Actividades Combinadas de Protracción
}

Fan-Yu Xu' ${ }^{1}$; Tae-Geon Kwon²; Hu Rong ${ }^{1}$; Hee-Moon Kyung ${ }^{2}$; Li Bing ${ }^{1}$ \& Xiu-Ping Wu ${ }^{1}$

XU, F. Y.; KWON, T. G.; RONG, H.; KYUNG, H. M.; BING, L. \& WU, X. P. Morphological changes of skeletal class III malocclusion in mixed dentition with protraction combined activities. Int. J. Morphol., 36(2):430-434, 2018.

SUMMARY. The objective of the study was to investigate the morphological changes of skeletal class III malocclusion in mixed dentition with light force protraction combined activities. Randomly selected 30 cases of orthodontics in Shanxi Medical University orthodontics patients (ages: 6-10 years) of the lateral cephalograms. Using the oral maxillary casting type of pre-traction device, according to the condition of maxillary dentition to select the corresponding activities of the movable expansion appliance, each side of the force of about 150-200 g, requiring patients to wear 10-12 hours a day, the appliance should be removed after reaching normal occlusion. The correlation cephalometric profile of the cranial lateral radiographs before and after orthodontic treatment was measured. All patients with skeletal class III malocclusion were improved, concave type became direct type, measurements SNA, ANB, A-Ptm, MP-SN, ANS-Me/N-Me increased, maxillary advancement and reconstruction are more obvious; mandible rotates clockwise; the increase of lip inclination of anterior teeth compensatory changes, lower anterior tooth inclination changes smaller; upper lip forward, nasolabial angle decreased, improved appearance significantly. Light force protraction combined activities can make the mixed dentition of skeletal class III malocclusion in patients with significant improvement in profile appearance.

KEY WORDS: Morphological characteristics; Skeletal class III malocclusion; Protraction; Cephalometric measurements; Mixed dentition.

\section{INTRODUCTION}

Skeletal class III malocclusion is the incidence of oral disease in the high incidence of malformations, the Asian population, especially children have a higher incidence of Chinese morbidity in the 5-12\% (Sun et al., 2015; Wu et al., 2017). Skeletal class III malocclusion often manifested as anterior crossbite or arch crossbite, compensatory lip of the upper anterior teeth and compensatory tongue of the lower anterior teeth, mesial occlusion of molar, soft tissue profile for concave type, hypoplasia of middle-face $1 / 3$, lower lip protruding (Liou, 2005; Akbari et al., 2016; Cabrita et al., 2017). Skeletal class III malocclusion is not only a significant effect on the function of children's oral and maxillofacial system, but also one of the common causes of temporomandibular joint dysfunction unsightly teeth and facial type will seriously affect children's mental health, resulting in children's inferiority complex (Song \& Wu, 2007; Heymann et al., 2010). Genetic factors and bad habits are the main cause of skeletal class III malocclusion, in the period of primary dentition and mixed dentition, the need for timely intervention in the treatment, among them, the patients in mixed dentition were treated with protraction (Ghassemi et al., 2014). In this study, we investigate the morphological changes of skeletal class III malocclusion in mixed dentition through light force protraction combined activities, to explore the improvement of the profile of the patients by this treatment, so as to guide the clinical work.

\section{MATERIAL AND METHOD}

Materials selection. Thirty patients (15 males and 15 females) were selected from September 2014 to August 2017 in the Department of orthodontics, Shanxi Medical University Stomatological Hospital.Inclusion criteria: 1) ages: 6-10 years; 2) skeletal class III malocclusion; 3 ) mesial

\footnotetext{
${ }^{1}$ Stomatology Hospital, Shanxi Medical University, Taiyuan, China.

${ }^{2}$ School of Dentistry, Kyungpook National University, Daegu, Korea.

Shanxi Province International Science and Technology Cooperation Project (China-Korea), No.2015081030;

Shanxi Province returned overseas students research funding projects, No.2015-053.
} 
molars relationship; 4) anterior crossbite and reverse overjer. Exclusion criteria: 1) history of orthodontic treatment or trauma; 2) oral and maxillofacial deformities and other systemic diseases affecting oral and maxillofacial development.

Instruments and equipment. There were head positioning X-ray camera (Siemens, Germany) and Winceph 8.0 cephalometric analysis system (Rise, Japan).

Experimental method. Thirty patients underwent a maxillary casting type of pre-traction device, according to the condition of maxillary dentition to select the corresponding activities of the movable expansion appliance, each side of the force of about $150 \mathrm{~g}-200 \mathrm{~g}$, requiring patients to wear 10-12 hours a day, the appliance should be removed after reaching the normal occlusion. The correlation cephalometric profile of the cranial lateral radiographs before and after orthodontic treatment was measured. 1) All patients were photographed by the same technician from the Department of Radiology of our hospital with the head positioning X-ray camera under the same condition; 2) The subject stood erect and looked straight ahead. With the head positioning X-ray camera, in intercuspal position, the face relaxed. The sagittal plane was parallel to the cassette; 3)Lateral radiographs of the skull were introduced into the Winceph 8.0 software. Cephalometric measurements were repeated three times by the same researcher at different times, the average value was calculated.

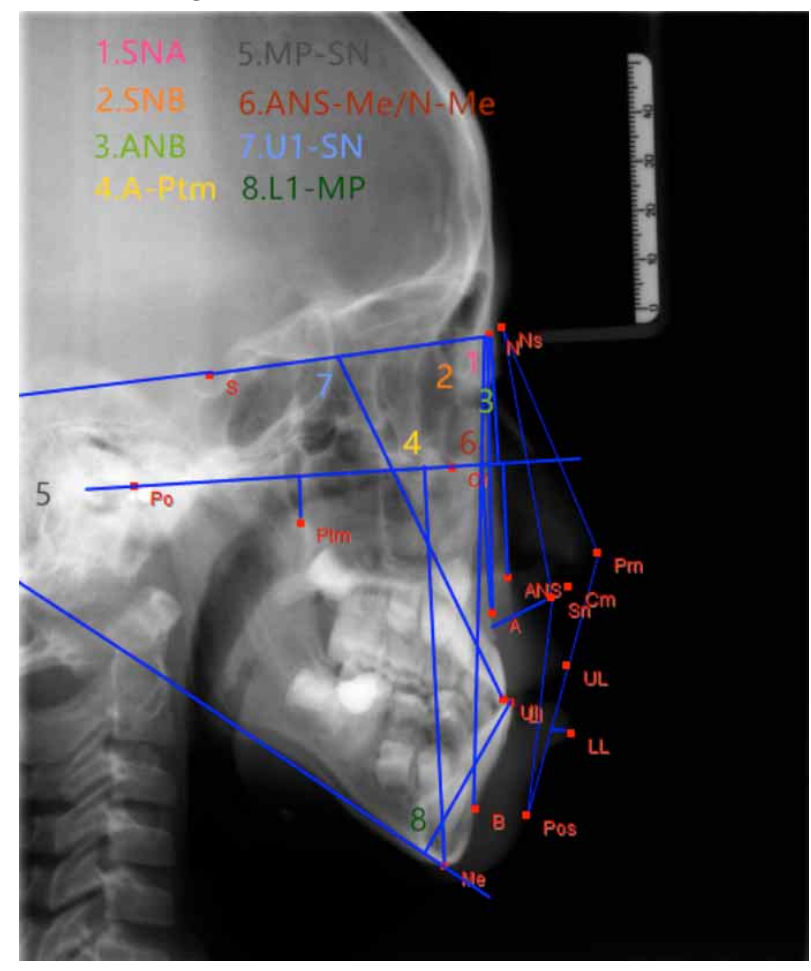

Fig. 1. Measurement index of hard tissue in cephalometric radiographs
Measurement index of hard tissue. 1) SNA: sella-nasionpoint A angle, representing the positional relationship (anterior and posterior) of the maxilla with respect to the skull; 2)SNB: sella-nasion-point B angle, representing the positional relationship (anterior and posterior) of the mandible relative to the skull; 3) ANB: AB plane angle, representing the positional relationship of the maxilla and mandible to the skull; 4) A-Ptm: representing the length of maxillary body; 5) MPSN: representing the steepness of the mandibular body; 6) ANS-Me/N-Me: lower face height to total face height ratio; 7) U1-SN: the inclination of the maxillary incisor relative to the SN plane; 8) L1-MP: The inclination of the mandibular incisor relative to the mandibular plane (Fig. 1).

Measurement indexes of soft tissue.1) Ns-Sn-Pos: representing facial profile of soft tissue profile in maxillofacial region; 2) TUL-E: representing the upper lip protrusion; 3)TLL-E: representing the lower lip protrusion; 4) Nasolabial angle: the angle between the lower edge of the nose and the leading edge of the upper lip 5) Upper lip base thickness: representing the upper lip thickness and protrusion (Fig. 2).

Statistical analysis. The data were processed by SPSS 22.0 software,the measurement data were expressed as $(x \pm s)$, and the paired t test was used before and after treatment. The difference was statistically significant $(\mathrm{P}<0.05)$.

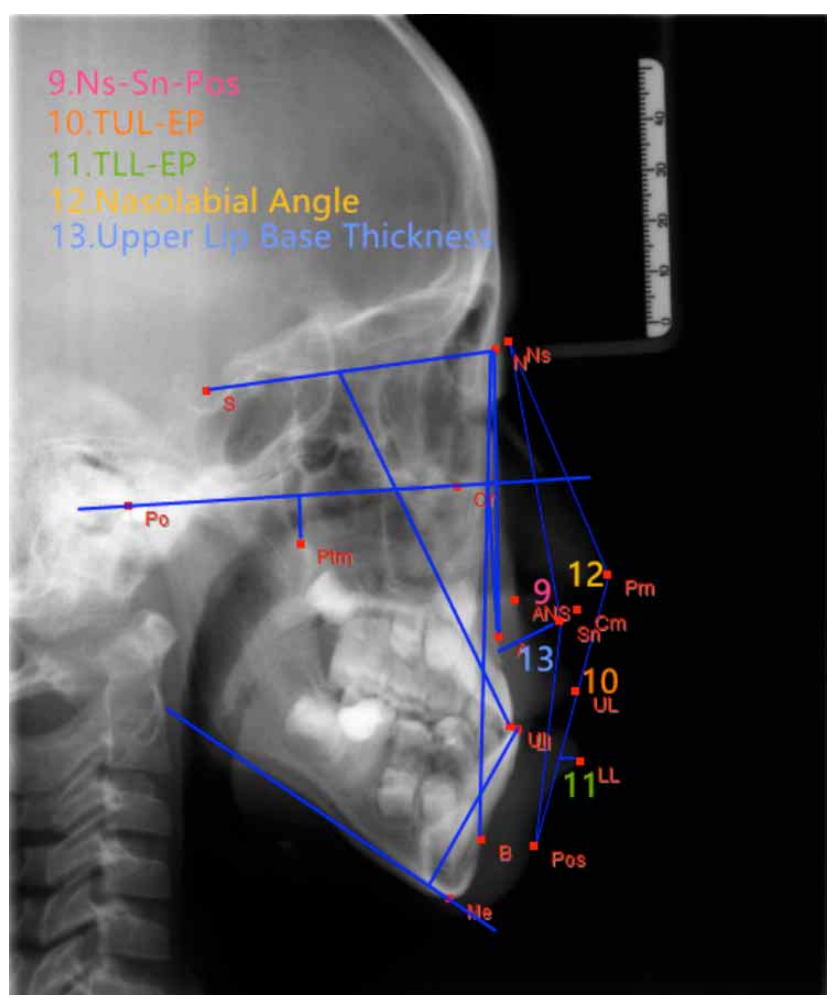

Fig. 2 . Measurement index of soft tissue in cephalometric radiographs. 


\section{RESULTS}

Clinical orthodontic treatment effect. Thirty patients with light force protraction combined activities for 6-10 months (mean 8.8 months) can make the mixed dentition of skeletal class III malocclusion in patients with a significant improvement in profile appearance, all patients of concave type became direct type. Twenty-one patients achieved normal occlusion, nine patients had shallow overbite.

\section{Changes of cephalometric measurement indexes after} orthodontic treatment. After treatment, SNA increased by $2.514^{\circ}(\mathrm{P}<0.05)$, ANB increased $3.452^{\circ}(\mathrm{P}<0.05)$, indicating that the maxillary move forward; A-Ptm increased $2.121 \mathrm{~mm}$, indicating that the maxilla also occurred growth. SNB decreased by $0.766^{\circ}(\mathrm{P}>0.05)$, indicating that the sagittal relationship between the Maxilla and mandible was significantly improved.MP-SN increased by $2.215^{\circ}$ $(\mathrm{P}<0.05)$. ANS-Me / N-Me increased by $1.091 \%(\mathrm{P}<0.05)$, which may be caused by clockwise rotation of mandible and growth and development during treatment.U1-SN increased $3.126^{\circ}(\mathrm{P}<0.05)$, indicating that the anterior teeth forward, the upper anterior teeth are slightly lip.L1-MP decreased by $1.102^{\circ}(\mathrm{P}>0.05)$, indicating that the lower anterior teeth no obvious after the shift and tilt. Ns-Sn-Pos increased by $5.784^{\circ}$ ( $\mathrm{P}<0.05)$, the upper lip forward $3.442 \mathrm{~mm}(\mathrm{P}<0.05)$, the lower lip retreated $0.363 \mathrm{~mm}(\mathrm{P}>0.05)$, the upper lip thickness decreased $1.782 \mathrm{~mm}(\mathrm{P}<0.05)$, the Nasolabial angle decreased by $5.629^{\circ}$ ( $\mathrm{P}<0.05$ ), indicating that the posterior side of the traction convex degree increased, the upper lip changes more obvious, and lower lip changes are not obvious (Table I).

Typical cases. Changes of facial and lateral radiographs before and after treatment of typical cases (Figs. 3 and 4).
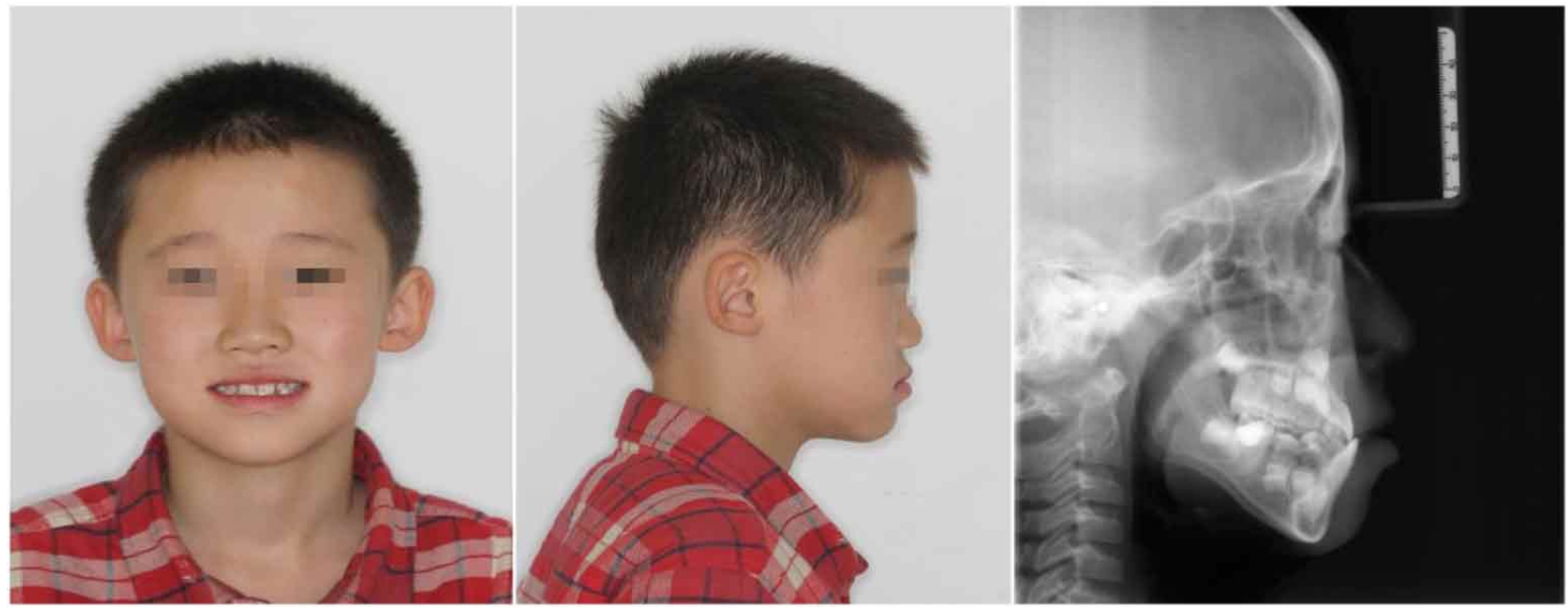

Fig. 3. Skeletal class III malocclusion patient before treatment.
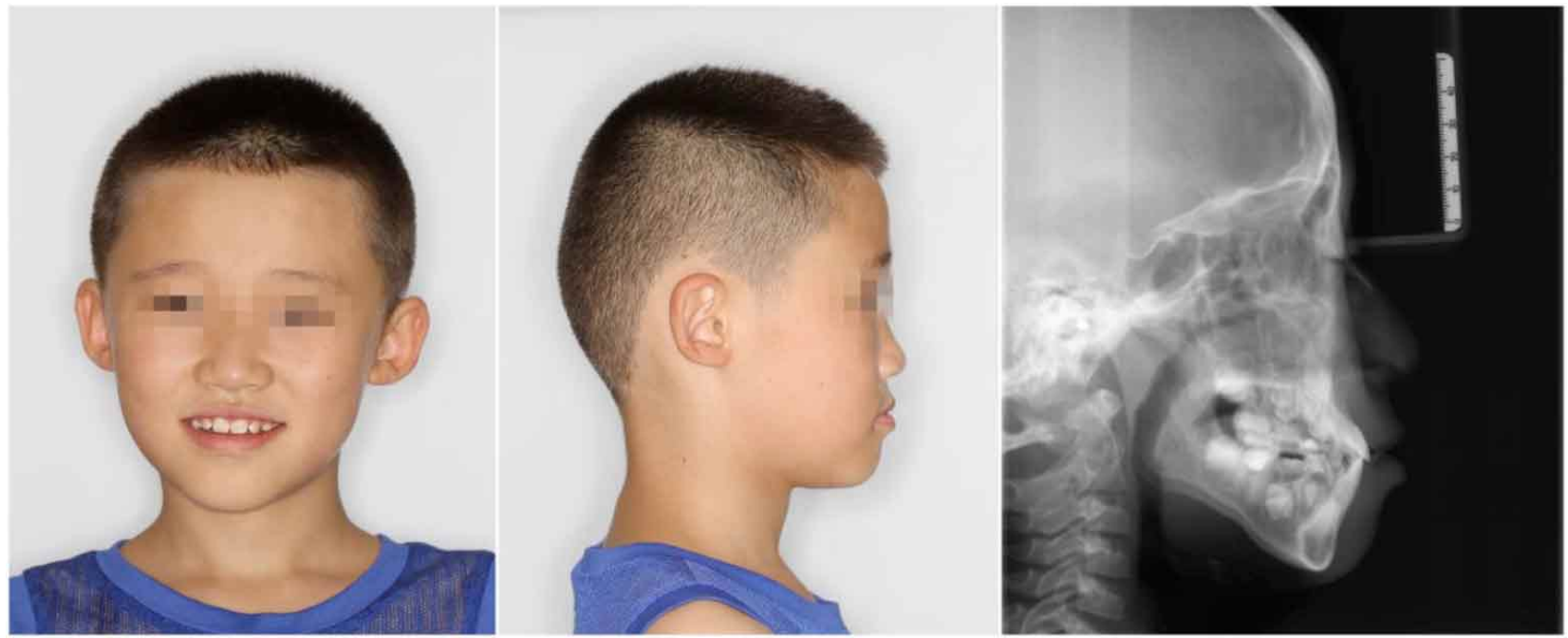

Fig. 4. Skeletal class III malocclusion patient after treatment. 
Table I. Correlative analysis of change of profile appearance indexes after treatment.

\begin{tabular}{lccc}
\hline Measurement indexes & $\begin{array}{c}\text { Changes before and after } \\
\text { orthodontic treatment_x } \pm \text { s__ }\end{array}$ & $\mathrm{t}$ & $\mathrm{p}$ \\
\hline SNA & $2.514 \pm 1.313$ & 3.28 & -0.05 \\
SNB & $-0.766 \pm 0.198$ & -1.27 & -0.05 \\
ANB & $3.452 \pm 1.232$ & 4.74 & -0.05 \\
A-Ptm & $2.121 \pm 0.342$ & 2.41 & -0.05 \\
MP-SN & $2.215 \pm 0.532$ & 1.98 & -0.05 \\
ANS-Me/N-Me & $1.091 \pm 0.934$ & 2.42 & -0.05 \\
U1-SN & $3.126 \pm 1.661$ & 2.88 & -0.05 \\
L1-MP & $-1.102 \pm 5.324$ & -1.77 & -0.05 \\
Ns-Sn-Pos & $5.784 \pm 3.452$ & -2.33 & -0.05 \\
TUL-EP & $3.442 \pm 2.212$ & 3.28 & -0.05 \\
TLL-EP & $-0.363 \pm 0.278$ & -1.34 & -0.05 \\
Nasolabial angle & $-5.629 \pm 4.652$ & 2.42 & 0.05 \\
Upper lip base thickness & $-1.782 \pm 2.219$ & -2.45 & -0.05 \\
\hline
\end{tabular}

\section{DISCUSSION}

Because the craniofacial morphology is complex, and the formation of skeletal class III malocclusion is closely related to individual inheritance, growth and development, environment and bad oral habits, clinical orthodontic treatment is more difficult (Lee et al., 1997; Gautam et al., 2009). Maxillary protraction is an important means of orthodontic treatment of skeletal class III malocclusion in mixed dentition, suitable for maxillary hypoplasia, maxillary retrusion of the patients, can promote the growth and development of the maxilla, this method has also been proved to have obvious growth and improvement effect for providing a more favorable environment for the normal development of the maxilla and mandible (Cordasco et al., 2014; Ngan \& Moon, 2015; Scherer et al., 2015).The timing of the treatment is about 8 years old, or after the eruption of the maxillary central incisor and the lateral incisor. Saadia \& Torres (2000) think that the maxillary deficiency cause of the skeletal class III malocclusion deformity through protraction treatment, in 3 children between the ages of 12 bones have changed, the deciduous dentition and early treatment time is relatively short and profile aesthetic changes more significantly. Mixed dentition is the rapid growth of the maxillofacial development period, the plasticity of the jaw is large and the degree of malformations is relatively mild protraction combined the maxillary expansion device can solve the maxillary width at the same time (Lee et al., 2010; Kim et al., 2017). In the treatment process, we must pay attention to relieve the bad habits of the mouth, correct the wrong sleeping posture. In order to avoid the rotation of the palatal plane counterclockwise, the direction of traction should be inclined with the plane before the $15-30^{\circ}$, the force of the line as far as possible through the center of the nasal maxillary complex, so that the maxillary movement of the overall movement to prevent the phenomenon of jaw opening. Scholars believe that the front of the soft tissue after the protraction correction straight, lip position improved, which is due to the establishment of the normal cover of the incisors, which makes the upper lip obtain better tension and morphology (Kiliçoglu \& Kirliç, 1998; Ozbilek et al., 2017). It was also found that the amount of forward movement of the maxillary soft tissue after protraction was 50-79\% of the amount of hard tissue moving forward, and the amount of anterior movement of the mandibular soft tissue was 71-81\% of the amount of hard tissue movement. After the treatment of soft tissue facial corners decreased, the upper lip more prominent, the upper lip can move forward $4.5 \mathrm{~mm}$, soft tissue pogonion backward shift, so that the face tends to balance. The upper anterior teeth forward $1.25 \mathrm{~mm}$ can make the upper lip corresponding forward $1 \mathrm{~mm}$, the thickness of upper lip decreased and the depth of upper lip sulcus was less, but the lower lip area change is not significant, which may be related to the lower lip position affected by a variety of factors.

The study of the pretraction force between 150-200 g, which reduces the damage caused by adverse gravity on the muscles and joints, While improving patient comfort and appliance retention performance, reducing the appliance off rate. Protraction combined activity expansion appliance to solve the maxillary sagittal and lateral problems, for protraction to achieve better results. Activity expansion device is also conducive to maintaining oral hygiene, easier access for parents and patients with the understanding and cooperation. The patients in the study in the 6 to 10 months of the correction process. A point of occurrence of significant forward, maxillary hypoplasia has been improved to varying degrees, the maxillary has moved forward and increased, the upper lip 
inclination is improved. The increase of MP-SN and ANS$\mathrm{Me} / \mathrm{N}-\mathrm{Me}$ is statistically significant, which indicates that the mandibular plane angle increases with the anterior and inferior hyperextension and the mandibular rotation occurs clockwise, which should be the result of the synergistic effect and growth and development. This suggests that the process of growth and development of patients with correction, should be combined with growth characteristics of correction. The cephalometric results showed the upper lip forward and lower lip backward, which makes up the deficiency of skeletal class III malocclusion concave profile, have been greatly improved.

In short, the light force protraction combined activities of the expansion of orthodontic treatment of skeletal class III malocclusion in mixed dentition, can create a good environment for the growth of maxilla and mandible, is beneficial to the normal growth of patients with maxillofacial development, improves the lateral appearance, increases patient self-confidence, reduces the difficulty of re-treatment of patients.

XU, F. Y.; KWON, T. G.; RONG, H.;KYUNG, H. M.;BING, L. \& WU, X. P. Cambios morfológicos en maloclusión de clase esquelética III en dentición mixta con actividades combinadas de protracción. Int. J. Morphol., 36(2) :430-434, 2018.

RESUMEN: El objetivo de este estudio fue investigar los cambios morfológicos de la maloclusión clase esquelética III, en la dentición mixta, con actividades combinadas de protracción de la fuerza ligera. Se seleccionaron aleatoriamente 30 casos de ortodoncia en pacientes de ortodoncia de la Universidad Médica de Shanxi (edades: 6-10 años) a partir de cefalogramas laterales, utilizando el tipo de dispositivo de pretracción de vaciado maxilar oral, de acuerdo con la condición de la dentición maxilar para seleccionar las actividades correspondientes del dispositivo de expansión móvil, cada lado con fuerza de alrededor de 150-200 g, requiriendo que los pacientes los utilizaran de 10 a 12 horas al día. El dispositivo debía ser retirado después de alcanzar la oclusión normal. Se midió el perfil cefalométrico de correlación de las radiografías laterales craneales, antes y después del tratamiento ortodóncico. Se observó mejoramiento en todos los pacientes con maloclusión de clase esquelética. Las mediciones SNA, ANB, APtm, MP-SN, ANS-Me / N-Me aumentaron, el avance y la reconstrucción maxilar fueron los cambios más significativos; la mandíbula giró en el sentido de las agujas del reloj, se observó un aumento de la inclinación labial de los dientes anteriores. Fue reducida la inclinación anterior del diente inferior, el ángulo nasolabial disminuyó y en general mejoró significativamente la apariencia. Las actividades combinadas de protrusión de la fuerza radiante pueden llevar a una mejora signficativa en el perfil de pacientes con dentición mixta de maloclusión clase III.

PALABRAS CLAVE: Características morfológicas; Maloclusión clase III; Prolongación; Mediciones cefalométricas; Dentición mixta.

\section{REFERENCES}

Akbari, M.; Lankarani, K. B.; Honarvar, B.; Tabrizi, R.; Mirhadi, H. \& Moosazadeh, M. Prevalence of malocclusion among Iranian children: A systematic review and meta-analysis. Dent. Res. J. (Isfahan), 13(5):387-95, 2016.

Cabrita, J. P.; Bizarra, M. F. \& Graça, S. R. Prevalence of malocclusion in individuals with and without intellectual disability: A comparative study. Spec. Care Dentist, 37(4):181-6, 2017.

Cordasco, G.; Matarese, G.; Rustico, L.; Fastuca, S.; Caprioglio, A.; Lindauer, S. J. \& Nucera, R. Efficacy of orthopedic treatment with protraction facemask on skeletal Class III malocclusion: a systematic review and meta-analysis. Orthod. Craniofac. Res., 17(3):133-43, 2014.

Gautam, P.; Valiathan, A. \& Adhikari, R. Maxillary protraction with and without maxillary expansion: a finite element analysis of sutural stresses. Am. J. Orthod. Dentofacial Orthop., 136(3):361-6, 2009.

Ghassemi, M.; Jamilian, A.; Becker, J. R.; Modabber, A.; Fritz, U. \& Ghassemi, A. Soft-tissue changes associated with different surgical procedures for treating class III patients. J. Orofac. Orthop., 75(4):299-307, 2014.

Heymann, G. C.; Cevidanes, L.; Cornelis, M.; De Clerck, H. J. \& Tulloch, J. F. Three-dimensional analysis of maxillary protraction with intermaxillary elastics to miniplates. Am. J. Orthod. Dentofacial Orthop., 137(2):274-84, 2010.

Kiliçoglu, H. \& Kirliç, Y. Profile changes in patients with class III malocclusions after Delaire mask therapy. Am. J. Orthod. Dentofacial Orthop., 113(4):45362, 1998.

Kim, K.; Choi, S. H.; Choi, E. H.; Choi, Y. J.; Hwang, C. J. \& Cha, J. Y. Unpredictability of soft tissue changes after camouflage treatment of Class II division 1 malocclusion with maximum anterior retraction using miniscrews. Angle Orthod., 87(2):230-8, 2017.

Lee, D. Y.; Kim, E. S.; Lim, Y. K. \& Ahn, S. J. Skeletal changes of maxillary protraction without rapid maxillary expansion. Angle Orthod., 80(4):504-10, 2010.

Lee, K. G.; Ryu, Y. K.; Park, Y. C. \& Rudolph, D. J. A study of holographic interferometry on the initial reaction of maxillofacial complex during protraction. Am. J. Orthod. Dentofacial Orthop., 111(6):623-32, 1997.

Liou, E. J. Effective maxillary orthopedic protraction for growing Class III patients: a clinical application simulates distraction osteogenesis. Prog. Orthod., 6(2): 154-71, 2005.

Ngan, P. \& Moon, W. Evolution of Class III treatment in orthodontics. Am. J. Orthod. Dentofacial Orthop., 148(1):22-36, 2015.

Ozbilek, S.; Gungor, A. Y. \& Celik, S. Effects of skeletally anchored Class II elastics: A pilot study and new approach for treating Class II malocclusion. Angle Orthod., 87(4):505-12, 2017.

Saadia, M. \& Torres, E. Sagittal changes after maxillary protraction with expansion in class III patients in the primary, mixed, and late mixed dentitions: a longitudinal retrospective study. Am. J. Orthod. Dentofacial Orthop., 117(6):669-80, 2000.

Scherer, J. M.; Sheats, R. D. \& Phillips, C. Class III bimaxillary orthognathic surgery and sleep disordered breathing outcomes. J. Dent. Sleep Med., 2(4):157-62, 2015.

Song, L. J. \& Wu, J. Cephalometric changes of the morphology of the symphysis after extraction in Angle Class II division 1 malocclusion patients. Shanghai Kou Qiang Yi Xue, 16(4):399-3, 2007.

Sun, B.; Tang, J.; Xiao, P. \& Ding, Y. Presurgical orthodontic decompensation alters alveolar bone condition around mandibular incisors in adults with skeletal Class III malocclusion. Int. J. Clin. Exp. Med., 8(8):12866-73, 2015.

Wu, X. P.; Xuan, J.; Liu, H. Y.; Xue, M. R. \& Bing, L. Morphological characteristics of the cranial base of early angle's Class II division 1 malocclusion in permanent teeth. Int. J. Morphol., 35(2):589-95, 2017.

Corresponding author:

Xiu-Ping Wu

Stomatology Hospital

Shanxi Medical University

63 Xinjian Road,Taiyuan 030001

CHINA

Received: 24-10-2017

Accepted: 27-12-2017

Email: libing-1975@163.com 